\title{
EARED GREBE, HORNED GREBE AND AMERICAN COOT INTERACTIONS
}

ANDRIUS VALADKA, 928 Bracewood Rise, Calgary, Alberta. T2W 3C9

On 26 May 1988 I searched a large pothole lake (about 20 ha) for photographic subjects. There were six pairs of Red-necked Grebes, six pairs of Eared Grebes and a group of five Piedbilled Grebes. While this lake had sup-

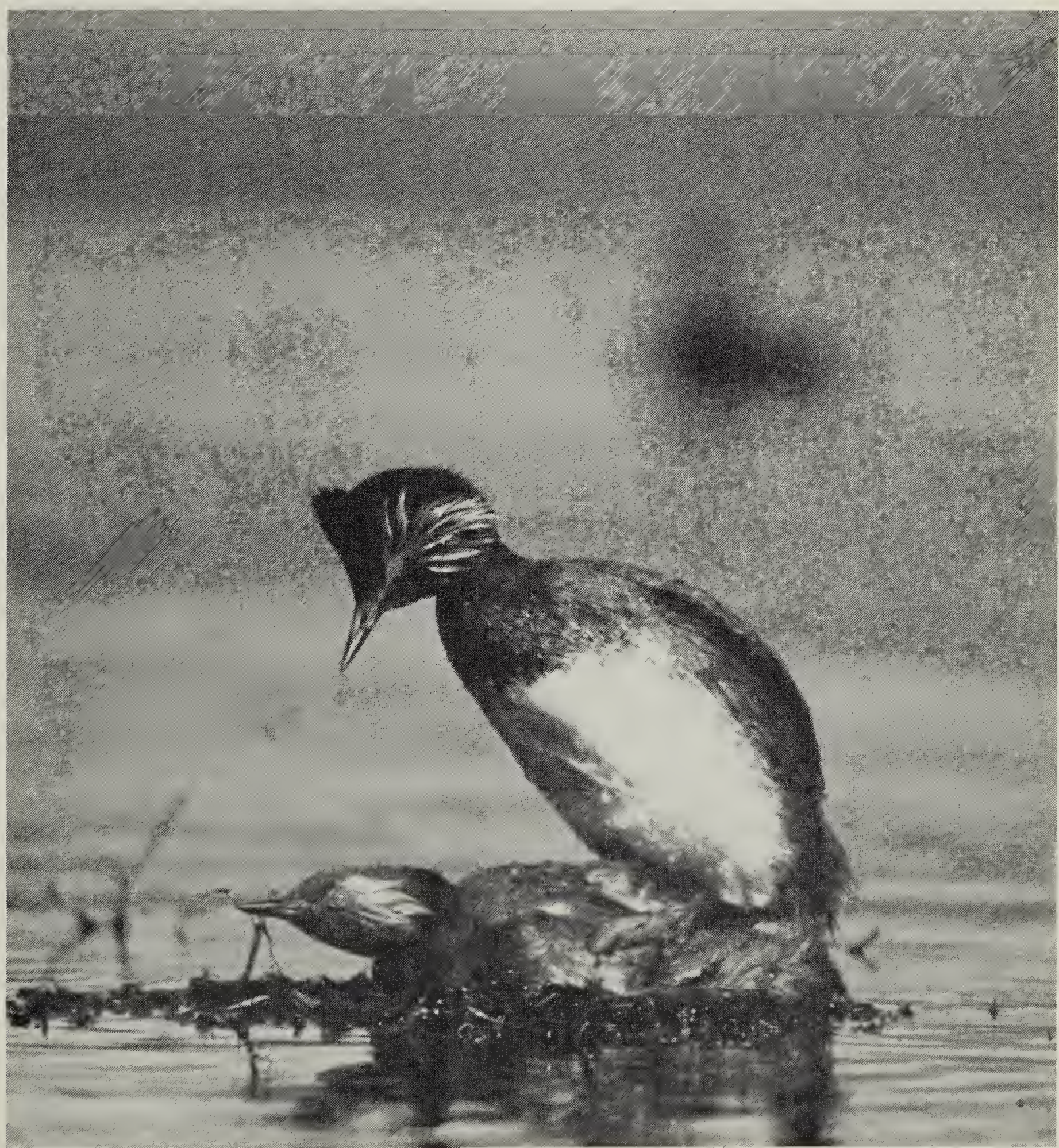


ported up to seven pairs of Red-necked Grebes in past years, I had never seen any other species of grebe there before. I attributed my good fortune to the fact that many sloughs and smaller lakes were drying up due to the extreme drought affecting the prairies.

Four days later I returned to find five pairs of Eared Grebes and a solitary Horned Grebe on a small cattail-bordered inlet of the lake. The following day two of the Eared Grebes were constructing a mating platform while the other four pairs milled about, apparently already paired up. The Horned Grebe was not seen.

On 1 June I set up a blind about $8 \mathrm{~m}$ from the mating platform and observed a single Eared Grebe pair mating on it. About $30 \mathrm{~m}$ from the platform a pair of American Coots was also mating at the shoreline.

On 2 June I spent 3.5 hours observing Eared Grebe solicitations, copulations and a penguin-like dance behaviour. The platform was also used by another pair of Eared Grebes after the first pair left to preen and loaf. A second platform was being constructed while I was there, about $20 \mathrm{~m}$ from the first. Towards the end of the evening a single Horned Grebe came to within 1-2 m of the second platform. Then a third pair of Eared Grebes began to attempt mating on this new platform. Most attempts were unsuccessful because the platform sank beneath the weight of the birds. Failed matings led to further nestbuilding activities.

The next evening $I$ found a second Horned Grebe in the inlet. The pair seemed to have monopolized both mating platforms. While they were mating on one, Eared Grebes moved in towards the other, occasionally having enough time to solicit and mate (about 3 to 4 minutes) before being driven off. The Horned Grebes did not break away from their own mating but chased away Eared Grebes while they were either undergoing post-coital preening or merely swimming about. Occasionally the Horned Grebes swam out toward deeper water and both mating platforms were used by the Eareds.

At one point while the female Horned was soliciting on the first platform and her mate preened adjacent to it, an American Coot swam towards them. The Horned Grebes abandoned the platform before the coot arrived. The coot preened on the platform for nearly 2 minutes, stamped about its surface and left. The Eared Grebes mated on that platform once more before I left, and the Horned Grebe pair preened by the other platform but did not mate again. While there have been many observations of coots interacting in an aggressive fashion with both Eared and Horned grebes, this is, I believe, the only known observation of both grebe species using the same mating platform (K. Cheng, pers. comm.).'

Following 3 days of heavy rain I returned to check on the state of the platforms on 8 June. One pair of Eared Grebes was observed mating in the rain and one pair was observed preening on the water. There was no sign of the Horned Grebes and the Eared Grebes disappeared the next day.

' LYNCH, W. 1977. Coots disturb Eared Grebe nests. Blue Jay 35(3):173. 